\title{
Decreased Serum Albumin Predicts Hypertension in a Japanese Health Screening Population
}

\author{
Eiji Oda
}

\begin{abstract}
Objective The serum albumin level has been reported to be positively associated with blood pressure in some cross-sectional studies. However, the longitudinal relationships between the serum albumin level and incident hypertension have been poorly studied.

Methods The incidence of hypertension was calculated for each quartile of serum albumin in 1,385 normotensive men and 855 normotensive women without cardiovascular disease at baseline who revisited for four years thereafter. The hazard ratios (HRs) of incident hypertension were calculated for each one SD increase in the serum albumin level and for the higher quartiles of serum albumin compared with the lowest quartile adjusted for smoking, alcohol drinking, body mass index, proteinuria, estimated glomerular filtration rate, uric acid, fasting glucose, log triglycerides, log high-sensitivity C-reactive protein, white blood cell count, hemoglobin, and systolic blood pressure.

Results During four years of follow-up (mean; 3.1 years), 242 men (17.5\%) and 89 women (10.4\%) developed hypertension. The incidence of hypertension significantly decreased through the quartiles of albumin $(\mathrm{p}$ for trend $=0.012)$. The HR (95\% confidence interval $(\mathrm{CI})$; $\mathrm{p}$ value) of hypertension for each one SD increase in the serum albumin level was $0.779(0.696-0.872 ;<0.001)$. Compared with the lowest quartile of serum albumin, the HRs (95\% CIs; p values) of hypertension for the second, third and fourth quartiles were 0.765 (0.574-1.018; 0.066), $0.628(0.440-0.895 ; 0.010)$ and $0.520(0.364-0.742 ;<0.001)$, respectively.
\end{abstract}

Conclusion A decreased serum albumin level was found to be a significant predictor of hypertension in a Japanese health screening population.

Key words: albumin, antioxidant, cardiovascular disease, hypertension

(Intern Med 53: 655-660, 2014)

(DOI: 10.2169/internalmedicine.53.1894)

\section{Introduction}

Hypertension has been established to be an independent risk factor for occurence and mortality of cardiovascular diseases (CVDs), including coronary heart disease, congestive heart failure, peripheral arterial disease, aortic aneurysm, cerebrovascular disease and chronic kidney disease. It is important to delineate predictors of hypertension so that appropriate strategies for further research on the prevention of morbidity and mortality of CVD can be developed. A high salt intake, obesity, sedentary life-style, and excess alcohol drinking are well-known risk factors for hypertension. A cross-sectional study reported that the heart rate, hematocrit, serum albumin, creatinine and body weight are positively, whereas serum potassium, smoking and age are inversely, associated with diastolic blood pressure (DBP), while serum albumin, high-density lipoprotein (HDL) cholesterol and age are positively, whereas serum potassium is inversely, associated with systolic blood pressure (SBP) in apparently healthy subjects (1). Another cross-sectional study reported that serum albumin level was positively associated with SBP and DBP only in non-Hispanic white men among a US population, controlling for age, an overweight status, alcohol intake, hematocrit, pulse, antihypertensive medication use and smoking (2). A cross-sectional and longitudinal study reported that serum albumin is associated with blood pressure only in cross-sectional models, not in longitudinal mod- 
els (3). As far as the author has reviewed, no studies have assessed the longitudinal association between serum albumin and incident hypertension, except for the above mentioned study (3). Hypertension is associated with endothelial dysfunction, insulin resistance, inflammation and oxidative stress (4-7) while albumin possesses an anti-inflammatory and antioxidant property (8). Therefore, contrary to the cross-sectional positive association observed between serum albumin and blood pressure, the baseline serum albumin level may be inversely associated with future hypertension. The present retrospective observational study investigated the association between the baseline serum albumin level and incident hypertension over four years in a Japanese health screening population.

\section{Materials and Methods}

\section{Subjects}

Between April 2008 and March 2009, 2,435 men and 1,437 women visited our Medical Check-up Center for annual general health screenings and provided their written informed consent. The visitors were required to complete a questionnaire including questions about their history of coronary heart disease and stroke, smoking, alcohol consumption, physical activity and use of antihypertensive, antidiabetic and antihyperlipidemic medications. Physical activity was defined as walking for one hour or longer per day or exercising for 30 minutes or longer twice or more per week. The inclusion criterion was normotension at baseline and the exclusion criteria were a history of coronary heart disease or stroke and the use of antihypertensive, antidiabetic or antihyperlipidemic medications at baseline. The possible candidates for this retrospective observational study included 1,538 men and 1,088 women. Among them, 1,385 men and 855 women revisited our Medical Check-up Center for annual health screenings conducted between April 2009 and March 2013 and were included in the present study. This study was approved by the ethics committee of Tachikawa Medical Center. Hypertension was defined as an SBP of $\geq 140 \mathrm{mmHg}$ and/or a DBP of $\geq 90 \mathrm{mmHg}$ and/or the use of antihypertensive medications.

\section{Measurements}

After an overnight fast, blood samples were obtained to measure the blood levels of routine medical check-up parameters, including fasting glucose, triglycerides, HDL cholesterol, low-density lipoprotein (LDL) cholesterol, hemoglobin A1c, uric acid, total protein, albumin, hemoglobin, total bilirubin, aspartate aminotransferase, alanine aminotransferase, gamma glutamyltransferase, highsensitivity C-reactive protein (CRP), white blood cells and creatinine. Proteinuria was qualitatively measured with a dipstick. The chemical assessments were all performed at BML Nagaoka (Nagaoka, Japan), except for the assessment of high-sensitivity CRP, which was performed at BML Gen- eral Laboratory (Tokyo, Japan) with nephelometry using Nlatex CRP-2 (Siemens Healthcare Japan, Tokyo, Japan). The measurement limit of high-sensitivity CRP was $0.02 \mathrm{mg} / \mathrm{L}$, and a value of high-sensitivity CRP less than the measurement limit was considered to be $0.01 \mathrm{mg} / \mathrm{L}$. LDL cholesterol was measured using a direct surfactant method with Choletest-LDL (Sekisui Medical Inc., Tokyo, Japan). The estimated glomerular filtration rate (GFR) was calculated as follows: estimated GFR $\left(\mathrm{mL} / \mathrm{min} / 1.73 \mathrm{~m}^{2}\right)=194 \times$ creatinine ${ }^{1.094} \times$ age $^{-0.287}$ in men, and $194 \times$ creatinine $^{-1.094} \times$ age $^{-0.287} \times 0.739$ in women according to the recommendation of the Japanese Society of Nephrology. Blood pressure was automatically measured with MPV-3301 (NIHON KODEN Inc., Tokyo, Japan). The average SBP and DBP values were calculated from two measurements obtained in the sitting position after five minutes of rest for each measurement. Body weight was measured with the subjects wearing light clothes provided by our Medical Check-up Center, and the weight of the clothes was subtracted from the measured body weight. The body mass index (BMI) was calculated as the weight in kilograms divided by the square of the height in meters.

\section{Statistical analysis}

Partial correlation coefficients between the serum albumin level and blood pressure and other laboratory parameters were calculated after being adjusted for sex, age, current smoking, daily alcohol drinking, physical activity and BMI.

The baseline data of the subjects who developed hypertension and those who did not were compared. The means were compared with two-sided $t$-tests and percentages were compared with chi-squared tests.

Pearson's correlation coefficients between changes in blood pressure per year and the baseline serum albumin level were calculated.

Hazard ratios (HRs) of incident hypertension were calculated for each one SD increase in the albumin level using the following four Cox regression models. Model 1 was adjusted for current smoking, daily alcohol drinking, BMI, proteinuria, estimated GFR, uric acid, fasting glucose, log triglycerides, log high-sensitivity CRP, white blood cells, hemoglobin and SBP. Except for proteinuria, these covariates differed between the subjects who developed hypertension and those who did not. Sex and age were not included in the covariates because they were already included in the estimated GFR. Model 2 was adjusted for sex, age, current smoking, daily alcohol drinking, BMI, proteinuria, creatinine, uric acid, fasting glucose, log triglycerides, log high-sensitivity CRP, white blood cells, hemoglobin and SBP. Model 3 was adjusted for current smoking, daily alcohol drinking, BMI, proteinuria, estimated GFR, uric acid, fasting glucose, log triglycerides, log high-sensitivity CRP, white blood cels, hemoglobin and DBP. Model 4 was adjusted for sex, age, current smoking, daily alcohol drinking, BMI, proteinuria, creatinine, uric acid, fasting glucose, log triglycerides, log high-sensitivity CRP, white blood cells, hemoglobin and DBP. SBP and DBP were separately included 
Table 1. Baseline Data of Candidates and Re-visitors

\begin{tabular}{|c|c|c|c|}
\hline & candidates & re-visitors & $\mathrm{p}$ \\
\hline $\mathrm{n}$ & 2,626 & 2,240 & \\
\hline male $(\%)$ & 58.6 & 61.8 & 0.021 \\
\hline age (years) & $49.4(9.0)$ & $49.8(8.7)$ & 0.090 \\
\hline current smoker $(\%)$ & 25.5 & 26.6 & 0.389 \\
\hline everyday drinker (\%) & 36.6 & 39.1 & 0.072 \\
\hline physical activity ${ }^{\mathrm{a}}(\%)$ & 34.4 & 34.1 & 0.812 \\
\hline body mass index $\left(\mathrm{kg} / \mathrm{m}^{2}\right)$ & $22.2(2.8)$ & $22.3(2.8)$ & 0.204 \\
\hline systolic blood pressure $(\mathrm{mmHg})$ & $112.0(12.4)$ & $113.1(12.6)$ & 0.002 \\
\hline diastolic blood pressure $(\mathrm{mmHg})$ & $70.9(8.2)$ & $71.8(8.4)$ & $<0.001$ \\
\hline uric acid (mg/dL) & $5.37(1.38)$ & $5.45(1.36)$ & 0.055 \\
\hline hemoglogin $(\mathrm{g} / \mathrm{dL})$ & $14.0(1.5)$ & $14.1(1.5)$ & 0.032 \\
\hline albumin $(\mathrm{g} / \mathrm{dL})$ & $4.31(0.22)$ & $4.30(0.22)$ & 0.417 \\
\hline total protein $(\mathrm{g} / \mathrm{dL})$ & $7.08(0.38)$ & $7.07(0.38)$ & 0.449 \\
\hline estimated GFR ${ }^{\mathrm{b}}\left(\mathrm{mL} / \mathrm{min} / 1.73 \mathrm{~m}^{2}\right)$ & $80.1(12.5)$ & $79.6(12.5)$ & 0.198 \\
\hline puroteinuria $(\%)$ & 2.9 & 2.7 & 0.594 \\
\hline fasting glucose $(\mathrm{mg} / \mathrm{dL})$ & $91.3(11.7)$ & $91.4(10.5)$ & 0.843 \\
\hline triglycerides (mg/dL) & $102.3(67.1)$ & $102.6(64.4)$ & 0.894 \\
\hline HDL cholesterol (mg/dL) & $61.9(15.2)$ & $61.9(15.1)$ & 0.883 \\
\hline LDL cholesterol (mg/dL) & $121.5(30.0)$ & $121.8(29.5)$ & 0.766 \\
\hline hemoglobin A1c (\%) & $4.99(0.40)$ & $4.99(0.35)$ & 0.681 \\
\hline hgigh-sensitivity $\mathrm{CRP}^{\mathrm{c}}(\mathrm{mg} / \mathrm{L})$ & $0.56(1.39)$ & $0.58(1.74)$ & 0.755 \\
\hline white blood cell count $\left(/ \mathrm{L}^{-6}\right)$ & $5,266(1,485)$ & $5,270(1,453)$ & 0.928 \\
\hline total bilirubin $(\mathrm{mg} / \mathrm{dL})$ & $0.81(0.33)$ & $0.81(0.34)$ & 0.889 \\
\hline aspartate aminotransferase (U/L) & $22.2(16.8)$ & $22.4(18.0)$ & 0.681 \\
\hline alanine aminotransferase (U/L) & $22.2(16.6)$ & $22.6(17.3)$ & 0.467 \\
\hline gamma glutamyltransferase (U/L) & $37.2(41.6)$ & $37.2(40.5)$ & 0.992 \\
\hline
\end{tabular}

in the adjusting covariates because Pearson's correlation coefficient between SBP and DBP was 0.897, indicating multicollinearity. The levels of triglycerides and high-sensitivity CRP were log transformed because their distributions were skewed.

The incidence of hypertension was calculated for each quartile of serum albumin, and the differences between each Kaplan-Meier survival curve of hypertension for the quartiles of serum albumin were examined using log-rank tests.

The HRs of hypertension for the higher quartiles of serum albumin compared with the lowest quartile were calculated using regression Model 1.

All calculations were performed using the Dr-SPSS-2 software program (IBM Japan, Tokyo, Japan). p values of less than 0.05 were considered to be statistically significant.

\section{Results}

The baseline data of the candidate and actually followed subjects are shown in Table 1. There were slight differences in the percentage of men, SBP, DBP, and hemoglobin between the candidates and followed subjects.

The partial correlation coefficients between serum albumin and blood pressure and other laboratory tests are presented in Table 2. There were weak but significant positive cross-sectional correlations between serum albumin and blood pressure at baseline.

During the four years of follow-up (mean; 3.1 years), 242 men $(17.5 \%)$ and 89 women $(10.4 \%)$ developed hypertension. The baseline data stratified according to the develop-
Table 2. Partial Correlation Coefficients between Serum Albumin

\begin{tabular}{|c|c|c|}
\hline & partial correlation coefficient $^{\mathrm{a}}$ & $\mathrm{p}$ \\
\hline systolic blood pressure & 0.096 & $<0.001$ \\
\hline diastolic blood pressure & 0.098 & $<0.001$ \\
\hline total protein & 0.600 & $<0.001$ \\
\hline hemoglobin & 0.282 & $<0.001$ \\
\hline uric acid & 0.123 & $<0.001$ \\
\hline fasting glucose & 0.102 & $<0.001$ \\
\hline triglycerides & 0.055 & 0.010 \\
\hline HDL cholesterol & 0.133 & $<0.001$ \\
\hline LDL cholesterol & 0.174 & $<0.001$ \\
\hline hemoglobin A1c & 0.036 & 0.094 \\
\hline high-sensitivity $\mathrm{CRP}^{\mathrm{b}}$ & -0.100 & $<0.001$ \\
\hline white blood cell count & -0.106 & $<0.001$ \\
\hline total bilirubin & 0.158 & $<0.001$ \\
\hline aspartate aminotransferase & 0.032 & 0.131 \\
\hline alanine amonotransferase & 0.121 & $<0.001$ \\
\hline gamma glutamyltransferase & 0.093 & $<0.001$ \\
\hline estimated GFR $^{\mathrm{c}}$ & -0.047 & 0.027 \\
\hline
\end{tabular}

Table 3. Baseline Data Stratified by the Development of Hypertension

\begin{tabular}{|c|c|c|c|}
\hline & developers & non-developers & $\mathrm{p}$ \\
\hline $\mathrm{n}$ & 331 & 1,909 & \\
\hline male sex $(\%)$ & 73.1 & 59.9 & $<0.001$ \\
\hline age (years) & $51.7(8.4)$ & $49.5(8.7)$ & $<0.001$ \\
\hline current smoker $(\%)$ & 32.0 & 25.6 & 0.015 \\
\hline everyday drinker $(\%)$ & 52.3 & 36.8 & $<0.001$ \\
\hline physical activity ${ }^{\mathrm{a}}(\%)$ & 35.6 & 33.8 & 0.509 \\
\hline body mass index $\left(\mathrm{kg} / \mathrm{m}^{2}\right)$ & $23.0(2.6)$ & $22.1(2.8)$ & $<0.001$ \\
\hline systolic blood pressure $(\mathrm{mmHg})$ & $122.1(11.7)$ & $111.6(12.0)$ & $<0.001$ \\
\hline diastolic blood pressure $(\mathrm{mmHg})$ & $78.5(7.4)$ & $70.6(8.0)$ & $<0.001$ \\
\hline uric acid (mg/dL) & $5.79(1.3$ & $5.39(1.36)$ & $<0.001$ \\
\hline hemoglogin $(\mathrm{g} / \mathrm{dL})$ & $14.4(1.4)$ & $14.1(1.5)$ & $<0.001$ \\
\hline albumin $(\mathrm{g} / \mathrm{dL})$ & $4.27(0.22)$ & $4.31(0.22)$ & 0.004 \\
\hline total protein $(\mathrm{g} / \mathrm{dL})$ & $7.05(0.38)$ & $7.07(0.38)$ & 0.226 \\
\hline estimated GFR ${ }^{\mathrm{b}}\left(\mathrm{mL} / \mathrm{min} / 1.73 \mathrm{~m}^{2}\right)$ & $77.8(12$ & $80.0(12.4)$ & 0.003 \\
\hline puroteinuria $(\%)$ & 3.9 & 2.5 & 0.127 \\
\hline fasting glucose (mg/dL) & $92.6(8.8)$ & $91.2(10.8)$ & 0.027 \\
\hline triglycerides $(\mathrm{mg} / \mathrm{dL})$ & $109.0(61.1)$ & $101.4(64.9)$ & 0.048 \\
\hline HDL cholesterol (mg/dL) & $61.1(14.7)$ & $62.1(15.2)$ & 0.284 \\
\hline LDL cholesterol (mg/dL) & $122.8(29.8)$ & $121.6(29.5)$ & 0.489 \\
\hline hemoglobin A1c (\%) & $5.00(0.30)$ & $4.99(0.36)$ & 0.587 \\
\hline hgigh-sensitivity $\mathrm{CRP}^{\mathrm{c}}(\mathrm{mg} / \mathrm{L})$ & $0.78(2.82)$ & $0.54(1.46)$ & 0.019 \\
\hline white blood cell count $\left(/ \mathrm{L}^{-6}\right)$ & $5,435(1,534)$ & $5,242(1,437)$ & 0.025 \\
\hline total bilirubin (mg/dL) & $0.81(0.35)$ & $0.81(0.34)$ & 0.745 \\
\hline aspartate aminotransferase (U/L) & $22.7(6.9)$ & $22.4(19.3)$ & 0.777 \\
\hline alanine aminotransferase (U/L) & $23.4(13.7)$ & $22.4(17.9)$ & 0.365 \\
\hline gamma glutamyltransferase (U/L) & $41.2(32.2)$ & $36.5(41.7)$ & 0.050 \\
\hline
\end{tabular}

mean (SD) or $\%,{ }^{a}$ walking for one hour or longer per day or exercising for 30 minutes or longer twice or more per week, ${ }^{\mathrm{b}}$ glomerular filtration rate, ${ }^{\mathrm{c}} \mathrm{C}$-reactive protein

ment of hypertension are shown in Table 3. A male sex, current smoking, daily drinking were more frequent, while age, BMI, SBP, DBP, uric acid, hemoglobin, fasting glucose, triglycerides, high-sensitivity CRP, and white blood cells were higher, and albumin and estimated GFR were lower in the subjects who developed hypertension than those who did not. Among the laboratory parameters that differed between the subjects who developed hypertension and those who did 
Table 4. Pearson's Correlation Coefficients (p Values) between Changes in Blood Pressures per Year and Baseline Serum Albumin

\begin{tabular}{lccc}
\hline & in all subjects & in men & in women \\
\hline changes in SBP $\mathrm{a} /$ year & $-0.115(<0.001)$ & $-0.144(<0.001)$ & $-0.056(0.101)$ \\
changes in DBP $/$ year & $-0.075(<0.001)$ & $-0.109(<0.001)$ & $-0.063(0.067)$ \\
\hline a endpoint systolic blood pressure minus baseline systolic blood pressure, \\
${ }^{\mathrm{b}}$ endpoint diastolic blood pressure minus baseline diastolic blood pressure
\end{tabular}

Table 5. Hazard Ratio (HR) of Hypertension for Each 1 SD Increase in Albumin

\begin{tabular}{|c|c|c|}
\hline & HR $(95 \%$ confidence interval $)$ & $\mathrm{p}$ \\
\hline \multicolumn{3}{|c|}{ in all subjects } \\
\hline Model $1^{\mathrm{a}}$ & $0.779(0.696-0.872)$ & $<0.001$ \\
\hline Model $2^{b}$ & $0.800(0.711-0.901)$ & $<0.001$ \\
\hline Model $3^{c}$ & $0.780(0.694-0.876)$ & $<0.001$ \\
\hline \multicolumn{2}{|r|}{ in men } & $<0.001$ \\
\hline Model $1^{\text {a }}$ & $0.765(0.663-0.883)$ & $<0.001$ \\
\hline Model $2^{b}$ & $0.815(0.698-0.952)$ & 0.010 \\
\hline Model $3^{\mathrm{c}}$ & $0.787(0.680-0.910)$ & 0.001 \\
\hline Model $4^{\mathrm{d}}$ & $\begin{array}{l}0.829(0.708-0.969) \\
\text { in women }\end{array}$ & 0.019 \\
\hline Model $1^{\mathrm{a}}$ & $0.836(0.689-1.013)$ & 0.068 \\
\hline Model $2^{b}$ & $0.837(0.691-1.014)$ & 0.069 \\
\hline Model $3^{c}$ & $0.800(0.660-0.970)$ & 0.023 \\
\hline Model $4^{\mathrm{d}}$ & $0.800(0.660-0.970)$ & 0.023 \\
\hline $\begin{array}{l}\text { drinking, } \\
\text { GFR, uric } \\
\text { high-sensit } \\
\text { hemoglobi } \\
\text { sex, age, c } \\
\text { body mass } \\
\text { fasting glu } \\
\text { CRP, white } \\
\text { blood pres } \\
\text { smoking, e } \\
\text { proteinuria } \\
\text { log triglyc } \\
\text { blood cell } \\
\text { pressure, } \\
\text { everyday } \\
\text { proteinuria } \\
\text { triglyceride } \\
\text { cell count, }\end{array}$ & $\begin{array}{l}\text { or current smoking, everyday } \\
\text { dy mass index, proteinuria, } \\
\text { id, fasting glucose, log triglyce } \\
\text { ty CRP, white blood cel } \\
\text { nd systolic blood pressure, }{ }^{\text {b ad }} \\
\text { ent smoking, everyday alcohol } \\
\text { ndex, proteinuria, creatinine, } \\
\text { se, log triglycerides, log high-s } \\
\text { lood cell count, hemoglobin an } \\
\text { re, c adjusted for adjusted fo } \\
\text { ryday alcohol drinking, body m } \\
\text { stimated GFR, uric acid, fasting } \\
\text { ides, log high-sensitivity CR } \\
\text { ount, hemoglobin and diasto } \\
\text { djusted for sex, age, current } \\
\text { cohol drinking, body mas } \\
\text { reatinine, uric acid, fasting glu } \\
\text { log high-sensitivity CRP, wh } \\
\text { moglobin and diastolic blood pr }\end{array}$ & $\begin{array}{l}\text { alcohol } \\
\text { stimated } \\
\text { ides, log } \\
\text { count, } \\
\text { usted for } \\
\text { drinking, } \\
\text { ric acid, } \\
\text { nsitivity } \\
\text { systolic } \\
\text { current } \\
\text { ss index, } \\
\text { glucose, } \\
\text { P, white } \\
\text { ic blood } \\
\text { moking, } \\
\text { index, } \\
\text { ose, log } \\
\text { te blood } \\
\text { essure }\end{array}$ \\
\hline
\end{tabular}

not, no laboratory parameters, except for the serum albumin level, were found to be significantly associated with incident hypertension after being adjusted for sex, age, current smoking, daily alcohol drinking, physical activity, BMI, and DBP (data not shown).

The Pearson's correlation coefficients between changes in blood pressure per year and the baseline serum albumin levels are presented in Table 4. The Pearson's correlation coefficient between changes in SBP/year and the baseline serum albumin level was $-0.115(\mathrm{p}<0.001)$, while that between changes in DBP/year and the baseline serum albumin level was $-0.075(\mathrm{p}<0.001)$ in all subjects.

The adjusted HRs of hypertension for each one SD increase in the serum albumin level are shown in Table 5. The serum albumin level was significantly associated with inci-
Table 6. Incidence of Hypertension by the Quartiles of Serum Albumin

\begin{tabular}{lccccr}
\hline & Q1 & Q2 & Q3 & Q4 & p for trend \\
\hline $\mathrm{n}$ & 543 & 795 & 372 & 530 & \\
albumin g/dL & $3.0-4.1$ & $4.2-4.3$ & $4.4-4.4$ & $4.5-5.0$ & \\
male sex \% & 52.7 & 58.2 & 66.7 & 73.2 & \\
age (SD) years & $52.7(8.8)$ & $50.4(8.3)$ & $49.6(8.3)$ & $46.3(8.5)$ & \\
incidence \% & 18.4 & 14.0 & 14.8 & 12.3 & 0.012 \\
\multicolumn{5}{c}{ p by log rank tests between each Kaplan-Meier survival curve } \\
Q2 & 0.026 & \multicolumn{4}{c}{} \\
Q3 & 0.136 & 0.728 & & \\
Q4 & 0.003 & 0.295 & 0.226 & \\
\hline
\end{tabular}

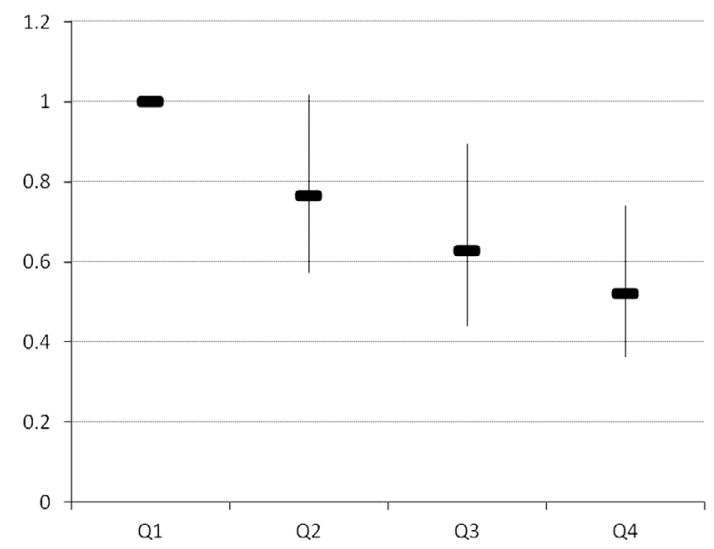

Figure. Hazard ratios of incident hypertension for the higher quartiles $(\mathbf{Q 2}, \mathbf{Q 3}$, and Q4) of serum albumin compared with the lowest quartile (Q1) adjusted for current smoking, daily alcohol drinking, body mass index, proteinuria, estimated glomerular filtration rate, uric acid, fasting glucose, log triglycerides, log high-sensitivity C-reactive protein, white blood cells, hemoglobin and systolic blood pressure

dent hypertension in all subjects in all models.

The incidence of hypertension stratified by the quartiles of serum albumin and the $p$ values between each KaplanMeier survival curve of hypertension are presented in Table 6. A significant linear trend in the incidence of hypertension was seen through the quartiles of serum albumin, and differences in the survival curves were significant between the lowest and second quartiles and between the lowest and highest quartiles.

The adjusted HRs of hypertension for the higher quartiles of albumin (Q2, Q3, and Q4) compared with the lowest quartile (Q1) are shown in Figure. The HRs (95\% confidence intervals; $\mathrm{p}$ values) of hypertension were 0.765 (0.574-1.018; 0.066), $0.628(0.440-0.895 ; 0.010)$ and 0.520 (0.364-0.742; <0.001) for Q2, Q3 and Q4, respectively.

\section{Discussion}

The present retrospective observational study demonstrated that the baseline serum albumin level was inversely correlated with future changes in blood pressure and that a decreased serum albumin level was a significant predictor of hypertension in a Japanese health screening population. 
The serum albumin level is reported to be positively associated with cross-sectional blood pressure (1-3), but not future blood pressure (3). In the cross-sectional Norwegian Oslo Health Study, an increase in serum albumin from approximately 4.0 to $5.0 \mathrm{~g} / \mathrm{dL}$ was associated with an increase in SBP/DBP of 5-11/3-7 mmHg in men and 6-17/4-9 $\mathrm{mmHg}$ in women, depending on age (9). In accordance with these reports, there were weak but significant positive crosssectional correlations between the serum albumin level and blood pressure at baseline. The cross-sectional positive association between the serum albumin level and blood pressure may be due to an increase in vascular volume caused by an increase in the concentration of serum albumin. As far as the author reviewed, there are no longitudinal studies examining the association between serum albumin and incident hypertension except for the above mentioned study (3), which reported no associations between the baseline serum albumin level and future blood pressure. In contrast to the positive cross-sectional correlations observed between the serum albumin level and blood pressure, the present study showed, for the first time, inverse longitudinal correlations between the serum albumin level and blood pressure.

A study using stored serum obtained from the Multiple Risk Factor Intervention Trial (10) reported an inverse association between the serum albumin level and the risk of coronary heart disease after adjusting for other cardiovascular risk factors. A prospective study using data obtained from the Framingham Offspring Study reported an inverse association between serum albumin and incidence of myocardial infarction (11). A follow-up study using data from the First National Health and Nutrition Examination Survey also reported inverse associations between the serum albumin level and the incidence and mortality of stroke (12). These findings are compatible with the results of the present study showing that a decreased serum albumin level is associated with incident hypertension because hypertension is a strong risk factor for morbidity and mortality from CVD.

A higher level of serum albumin may protect against the development of hypertension and CVD because hypertension is associated with endothelial dysfunction, insulin resistance, inflammation and oxidative stress (4-7), while albumin possesses both anti-inflammatory and antioxidant properties (8). Albumin inhibits copper-stimulated peroxidation and hemolysis as well as the production of free hydroxyl radicals from systems containing copper ions and $\mathrm{H}_{2} \mathrm{O}_{2}$ (13). Serum albumin may also inhibit endothelial apoptosis (14). However, other mechanisms than inflammation may be involved in the association between the serum albumin level and incident hypertension because the association is independent of the high-sensitivity CRP and white blood cell count, both of which are markers of systemic inflammation.

Significant independent inverse relationships have been reported between blood pressure and both 24-hour urinary total nitrogen and urea nitrogen adjusted for age, sex, alcohol intake, BMI, and 24-hour urinary sodium, potassium, calcium, and magnesium (15), which suggests an inverse as- sociation between protein intake and blood pressure. Although the relationship between the dietary protein intake and blood pressure remains controversial $(16,17)$, recent evidence from randomized controlled trials suggests that an increased intake of protein may lower blood pressure (18-25). The slightly decreased levels of serum albumin observed in apparently healthy subjects in the present study may possibly result from an inadequate protein intake. Alternatively, decreased levels of serum albumin may be caused by albuminuria which is reported to be a predictor of incident hypertension $(26,27)$. Albuminuria is related to glomerular and systemic endothelial dysfunction, which is thought to be a major causal mechanism of hypertension.

\section{Limitations}

The present study is not a prospective follow-up study, but rather a retrospective observational study. Furthermore, the subjects of the present study were not from a general population, but rather from a health screening population. Among the 2,626 candidate subjects, 386 individuals (14.6\%) dropped-out, and some baseline data were slightly different between the candidates and followed subjects. In this study, hypertension was diagnosed at only one time point and may have included white coat hypertension. No dietary information was available, except for the habits of smoking and alcohol drinking. In addition, the urinary excretion of albumin was not measured in this study.

\section{Conclusion}

The present study found that a decreased level of serum albumin was a significant predictor of hypertension in a Japanese health screening population. As far as the author has reviewed, there are no reports showing an inverse association between the serum albumin level and incident hypertension.

\section{The author states that he has no Conflict of Interest (COI).}

\section{Acknowledgement}

The author thanks all subjects who participated in the study, the paramedical staff at our center who assisted with the study, and Honorary Prof. Yoshifusa Aizawa at Tachikawa Medical Center.

\section{References}

1. Tell GS, Rutan GH, Kronmal RA, et al. Correlates of blood pressure in community-dwelling older adults. The Cardiovascular Health Study. Cardiovascular Health Study (CHS) Collaborative Research Group. Hypertension 23: 59-67, 1994.

2. Vargas CM, Obisesan T, Gillum RF. Association of serum albumin concentration, serum ionized calcium concentration, and blood pressure in the Third National Health and Nutrition Examination Survey. J Clin Epidemiol 51: 739-746, 1998.

3. Hu H, Sparrow D, Weiss S. Association of serum albumin with blood pressure in the normative aging study. Am J Epidemiol 136: 1465-1473, 1992. 
4. Reaven GM. Role of insulin resistance in human disease. Diabetes 37: 1595-1607, 1988.

5. Reaven GM, Lithell H, Landsberg L. Hypertension and associated metabolic abnormalities: the role of insulin resistance and the sympathoadrenal system. N Engl J Med 334: 374-381, 1996.

6. Katagiri H, Yamada T, Oka Y. Adiposity and cardiovascular disorders: disturbance of the regulatory system consisting of humoral and neuronal signals. Circ Res 101: 27-39, 2007.

7. Oda E. Metabolic syndrome: its history, mechanisms, and limitations. Acta Diabetol 49: 89-95, 2012.

8. Halliwell B. Albumin: an important extracellular antioxidant? Biochem Pharmacol 37: 569-571, 1988.

9. Høstmark AT, Tomten SE, Berg JE. Serum albumin and blood pressure: a population-based, cross-sectional study. J Hypertens 23: 725-730, 2005.

10. Kuller LH, Eichner JE, Orchard TJ, Grandits GA, McCallum L, Tracy RP. The relation between serum albumin levels and risk of coronary heart disease in the Multiple Risk Factor Intervention Trial. Am J Epidemiol 134: 1266-1277, 1991.

11. Djoussé L, Rothman KJ, Cupples LA, Levy D, Ellison RC. Serum albumin and risk of myocardial infarction and all-cause mortality in the Framingham Offspring Study. Circulation 106: 2919-2924, 2002.

12. Gillum RF, Ingram DD, Makuc DM. Relation between serum albumin concentration and stroke incidence and death: the NHANES I Epidemiologic Follow-up Study. Am J Epidemiol 140: 876-888, 1994.

13. Wayner DD, Burton GW, Ingold KU, Locke S. Quantitative measurement of the total, peroxyl radical-trapping antioxidant capability of human blood plasma by controlled peroxidation: the important contribution made by plasma proteins. FEBS Lett 187: 33-37, 1985.

14. Zoellner H, Hofler M, Beckmann R, et al. Serum albumin is a specific inhibitor of apoptosis in human endothelial cells. J Cell Sci 109: 2571-2580, 1996.

15. Stamler J, Elliott $P$, Kesteloot $H$, et al. Inverse relation of dietary protein markers with blood pressure. Findings for 10,020 men and women in the INTERSALT Study. INTERSALT Cooperative Research Group. INTERnational study of SALT and blood pressure. Circulation 94: 1629-1634, 1996.

16. Obarzanek E, Velletri PA, Cutler JA. Dietary protein and blood pressure. JAMA 275: 1598-1603, 1996.

17. He J, Whelton PK. Effect of dietary fiber and protein intake on blood pressure: a review of epidemiologic evidence. Clin Exp Hypertens 21: 785-796, 1999.

18. Appel L, Moore T, Obarzanek E, et al. A clinical trial of the effects of dietary patterns on blood pressure. $\mathrm{N}$ Engl J Med 336: 1117-1124, 1997.

19. Washburn S, Burke G, Morgan T, Anthony M. Effect of soy protein supplementation on serum lipoproteins, blood pressure, and menopausal symptoms in perimenopausal women. Menopause 6: 7-13, 1999

20. Burke V, Hodgson JM, Beilin LJ, Giangiulioi N, Rogers P, Puddey IB. Dietary protein and soluble fiber reduce ambulatory blood pressure in treated hypertensives. Hypertension 38: 821-826, 2001.

21. Appel LJ, Sacks FM, Carey VJ, et al. Effects of protein, monounsaturated fat, and carbohydrate intake on blood pressure and serum lipids: results of the OmniHeart randomized trial. J Am Med Assoc 294: 2455-2464, 2005.

22. Hodgson JM, Burke V, Beilin LJ, Puddey IB. Partial substitution of carbohydrate intake with protein intake from lean red meat lowers blood pressure in hypertensive persons. Am J Clin Nutr 83: 780-787, 2006.

23. Wang YF, Yancy WS Jr, Yu D, Champagne C, Appel LJ, Lin PH. The relationship between dietary protein intake and blood pressure: results from the PREMIER study. J Hum Hypertens 22: 745754, 2008.

24. Rebholz CM, Friedman EE, Powers LJ, Arroyave WD, He J, Kelly TN. Dietary protein intake and blood pressure: a metaanalysis of randomized controlled trials. Am J Epidemiol 176 (Suppl 7): S27-S43, 2012.

25. Tielemans SM, Altorf-van der Kuil W, Engberink MF, et al. Intake of total protein, plant protein and animal protein in relation to blood pressure: a meta-analysis of observational and intervention studies. J Hum Hypertens 27: 564-571, 2013.

26. Brantsma AH, Bakker SJ, de Zeeuw D, de Jong PE, Gansevoort RT. Urinary albumin excretion as a predictor of the development of hypertension in the general population. J Am Soc Nephrol 17: 331-335, 2006.

27. Forman JP, Fisher ND, Schopick EL, Curhan GC. Higher levels of albuminuria within the normal range predict incident hypertension. J Am Soc Nephrol 19: 1983-1988, 2008.

(C) 2014 The Japanese Society of Internal Medicine http://www.naika.or.jp/imonline/index.html 